\title{
Imunologi Human Immunodeficiency Virus (HIV) dalam Kehamilan
}

\author{
Maya Savira ${ }^{1}$
}

\begin{abstract}
Human Immunodeficiency Virus can be spread through sexual contact, blood products and vertical transmission of the mother to the fetus. The high incidence of HIV / AIDS around the world in women over 15 years old and children under the age of 15 years gives an overview of HIV / AIDS cases in pregnant women likely to have a high incidence. HIV viral RNA viruses belonged to two different types, namely HIV - 1 and HIV - 2 . Most cases are caused by HIV - 1. HIV primarily infects CD4 lymphocytes or T helper ( Th ), the numbers will decrease, as well as the function of the immune system will decrease. During pregnancy occurs emphasis on immune cells, with or without HIV infection. Study in France showed no significant progression between the immune system of pregnant women with HIV and normal pregnant women. T reg on HIV infection in lymphoid tissue accumulated and the number of T reg post partum was higher in patients with HIV infection compared to HIV- negative. Human Leukocyte antigen - G ( HLA - G ) inhibits cell-mediated immune response and can penetrate the placenta spread of HIV - 1 infection and increase the risk of vertical transmission. Major histocompatibility complex ( MHC) encodes HLA - G to inhibit natural killer cells ( NK cells) that supports the entry of the virus passes through the placental barrier in HIV- 1 positive pregnant women . HIV infection activates CD8 expressing HLA - DR antigen . CD8 immune activation in chronic HIV becomes a factor decreasing CD4 count . The expression of HLA - DR and CD38 on CD8 T lymphocytes that recognize CD4 eliminated by HIV infection Total CD8, CD38, and HLA - DR is reduced in HIV-positive pregnant women may be a prognostic parameters of immune status .
\end{abstract}

Key word : Human Immunodeficiency Virus (HIV), pregnant women, CD4

\section{EPIDEMIOLOGI}

Tingkah laku, kehidupan sosial dan budaya yang berbeda menentukan karakteristik penyakit HIV di setiap daerah. Transmisi HIV dapat melalui 3 jalur : hubungan seksual, heterosexual, homoseksual yang tidak aman; melalui produk darah; dan transmisi vertikal ibu ke anak (vertical mother to child transmission). $65 \%$ infeksi dihasilkan oleh pasangan heteroseksual yang tidak menggunakan kondom. ${ }^{1}$ Data - data WHO mengenai HIV/AIDS menunjukkan 2011 menunjukkan sekitar 34 juta manusia pada tahun 2011 di seluruh dunia hidup dengan HIV/AIDS dengan angka kematian mencapai 1,7 juta manusia. Data WHO 2011 menunjukkan 3,3 juta anak dibawah usia 15 tahun di seluruh dunia hidup

${ }^{1}$ Bagian Mikrobiologi Fakultas Kedoteran Universitas Riau dengan HIV/AIDS, sedangkan pada wilayah Asia Tenggara kasus HIV/AIDS pada anak usia dibawah 15 tahun mencapat 140.000 kasus. ${ }^{1}$ Kasus HIV/ AIDS di Indonesia mencapai angka 380.000 pasien dengan kasus wanita diatas umur 15 tahun mencapai 110.000 kasus. $^{2}$ Data mengenai kasus HIV/AIDS pada ibu hamil ataupun anak dibawah usia 15 tahun belum dilaporkan. Tingginya angka kejadian HIV/ AIDS pada wanita usia diatas 15 tahun ditakutkan tingginya angka HIV/AIDS pada ibu hamil.

\section{STRUKTUR HIV}

Virus HIV termasuk golongan RNA yang berbentuk sferis dengan inti kerucut, dikelilingi oleh selubung lipid yang berasal dari membran sel hospes diameter 1000 angstrom. Inti virus mengandung protein kapsid terbesar yaitu p24, protein nukleokapsid p7/p9, dua kopi RNA genom, dan 
tiga enzim virus yaitu protease, reverse transcriptase dan integrase. Protein p24 adalah antigen virus yang cepat terdeteksi dan merupakan target antibodi dalam tes screening HIV. Inti virus dikelilingi oleh matriks protein p17, yang merupakan lapisan di bawah selubung lipid. Sedangkan selubung lipid virus mengandung dua glikoprotein yang sangat penting dalam proses infeksi HIV dalam sel yaitu gp120 dan gp41. Genom virus yang berisi gen $g a g$, pol, dan env yang akan mengkode protein virus. Hasil translasi berupa protein prekursor yang besar dan harus dipotong oleh protease menjadi protein matang.1,2

Human Immunodeficiency Virus (HIV) merupakan kelompok virus RNA, famili: Retroviridae, sub famili : Lentivirinae, genus : Lentivirus, spesies : Human Immunodeficiency Virus 1 (HIV-1) dan Human Immunodeficiency Virus 2 (HIV-2).

Terdapat dua tipe yang berbeda dari virus AIDS manusia, yaitu HIV-1 dan HIV-2. Kedua tipe dibedakan berdasarkan susunan genom dan hubungan filogenetik (evolusioner) dengan lentivirus primata lainnya. Perbedaan struktur genom ini walaupun sedikit, diperkirakan mempunyai peranan dalam menentukan patogenitas dan perbedaan perjalanan penyakit diantara kedua tipe HIV tersebut. Human Immunodeficiency Virus 1 (HIV-1) yang lebih sering ditemukan, maka penelitian-penelitian klinis dan laboratoris lebih sering dilakukan terhadap HIV-1.

\section{SIKLUS HUMAN IMMUNODEFICIENCY VIRUS}

Human Immunodeficiency Virus merupakan retrovirus obligat intraselular dengan replikasi sepenuhnya di dalam sel host. Perjalanan infeksi HIV di dalam tubuh manusia diawali dari interaksi gp120 pada selubung HIV berikatan dengan reseptor spesifik CD4 yang terdapat pada permukaan membran sel target (kebanyakan limfosit T-CD4+). Sel target utama adalah sel yang mempu mengekspresikan reseptor $\mathrm{CD} 4$ (astrosit, mikroglia, monosit-makrofag, limfosit, Langerhan's dendritik). ${ }^{3}$ Glikoprotein terdiri dari dua sub-unit gp120 dan gp41. ${ }^{4}$ Sub unit 120 mempunyai afinitas tinggi terhadap reseptor CD4 dan bertanggung jawab untuk ikatan awal virus pada sel. Perlekatan ini menginduksi perubahan konformasi yang memicu perlekatan kedua pada koreseptor. Dua reseptor kemokin utama yang digunakan oleh HIV adalah CCR5 dan CXCR4. ${ }^{5}$ Ikatan dengan kemoreseptor ini menginduksi perubahan konformasi pada sub unit glikoprotein 41 (gp41) yang mendorong masuknya sekuens peptida gp41 ke dalam membran target yang memfasilitasi fusi virus. Setelah terjadinya fusi, virus tidak berselubung mempersiapkan untuk mengadakan replikasi.

Material genetik virus adalah RNA single stand-sense positif (ssRNA), virus harus mentranskripsi RNA ini dalam DNA secara optimal pada replikasi sel manusia (transkripsi normal terjadi dari DNA ke RNA, HIV bekerja mundur sehingga diberi nama retrovirus). Untuk melakukannya HIV dilengkapi dengan enzim unik RNA-dependent DNA polymerase (reverse transcriptase). Reverse transcriptase pertama membentuk rantai DNA komplementer, menggunakan RNA virus sebagai templet. Hasil sintesa lengkap molekul double-strand DNA (dsDNA) dipindahkan ke dalam inti dan berintegrasi ke dalam kromoson sel tuan rumah oleh enzim integrase. Integrasi ini menimbulkan beberapa masalah, pertama HIV dapat menyebabkan infeksi kronik dan persisten, umumnya dalam sel sistem imun yang berumur panjang seperti Tlimfosit memori. Kedua, pengintegrasian acak menyebabkan kesulitan target. Selanjutnya integrasi acak pada HIV ini menyebabkan kelainan seluler dan mempengaruhi apoptosis. Gabungan DNA virus dan DNA sel inang akan mengalami replikasi, transkripsi dan translasi. DNA polimerase mencatat dan mengintegrasi provirus DNA ke mRNA, dan mentranslasikan pada mRNA sehingga terjadi pembentukan protein virus. Pertama, transkripsi dan translasi dilakukan dalam tingkat rendah menghasilkan berbagai protein virus seperti Tat, Nef dan Rev. Protein Tat sangat berperan untuk ekspresi gen HIV, mengikat pada bagian DNA spesifik yang memulai dan menstabilkan perpanjangan transkripsi. Belum ada fungsi yang jelas protein Nef. Protein Rev mengatur aktivitas post transkripsional dan sangat dibutuhkan untuk reflikasi HIV. Perakitan partikel virion baru dimulai dengan penyatuan protein HIV dalam sel inang. Nukleokapsid yang 
sudah terbentuk oleh ssRNA virus disusun dalam satu kompleks. Kompleks nukleoprotein ini kemudian dibungkus dengan 1 membran pembungkus dan dilepaskan dari sel pejamu melalui proses "budding" dari membran plasma. Kecepatan produksi virus dapat sangat tinggi dan menyebabkan kematian sel. $^{6}$

\section{MEKANISME IMUN NORMAL}

Aktivasi sel Th dalam keadaan normal terjadi pada awal terjadinya respon imunitas. Th dapat teraktivasi melalui dua sinyal, yaitu: pertama terikatnya reseptor Ag -TCR (T Cell Receptor) dengan kompleks Antigen- molekul MHC Clas II yang dipresentasikan oleh makrofag sebagai antigen presenting cells (APCs) yang teraktivasi oleh antigen. Sinyal kedua berasal dari Sitokin IL-1 yang dihasilkan oleh APC yang teraktivasi tadi. Kedua sinyal tadi akan merangsang Th mengekspresikan reseptor IL-2 dan produksi IL-2 dan sitokin lain yang dapat mengaktivasi makrofag, CTLs (cytotoxic T Lymphocyte atau TC) dan sel limfosit B. IL-2 juga akan berfungsi autoaktivasi terhadap sel Th semula dan sel Th lainnya yang belum memproduksi IL-2 untuk berproliferasi. Jadi dengan demikian akan terjadi amplifikasi respon yang diawali oleh kontak APCs dengan sel Th semula. Aktivasi sel Tc yang berfungsi untuk membunuh benda asing atau nonself-antigen. Sel Tc dapat dibedakan dengan Th karena Tc mempunyai molekul CD8 dan akan mengenal antigen asing melalui molekul MHC class I. Seperti sel Th, sel Tc juga teraktivasi melalui dua sinyal, yaitu sinyal pertama adalah interaksi reseptor Ag-TCR dengan kompleks epitope benda asing dan molekul MHC Class I. Sel tersebut bisa berupa sel tumor atau jaringan asing. Sinyal kedua adalah rangsangan dari sitokin IL-2 yang diproduksi oleh sel Th tersebut. Tangan ke tiga dari imunitas seluler di lakukan oleh sel NK (natural killer), yaitu sel limfosit dengan granula kasar dengan petanda CD16 dan CD56. Fungsinya secara non spesifik menghancurkan langsung sel-sel asing, sel tumor atau sel terinfeksi virus. Atau juga dengan cara spesifik untuk sel-sel yang di lapisi oleh antibody dependent cell mediated cytotoxicity (ADCC). Aktivasi sel limfosit B memerlukan paling sedikit tiga sinyal, yaitu pertama oleh imunogen yang terikat pada reseptor antigen, dan dua sinyal lainnya adalah limfokin BCDF (B cell differentiaton factor) dan BCGF (B cell growth factor) yang di produksi oleh sel TH yang teraktivasi. Dengan aktivasi sel limfosit $\mathrm{B}$, maka akan terjadi pertumbuhan dan differensiasi sel limfosit B menjadi sel plasma sebagai sel yang akan memproduksi antibodi.

\section{PENGARUH HIV TERHADAP SISTEM IMUN}

Human Immunodeficiency Virus terutama menginfeksi limfosit CD4 atau T helper (Th), sehingga dari waktu ke waktu jumlahnya akan menurun, demikian juga fungsinya akan semakin menurun. Th mempunyai peranan sentral dalam mengatur sistem imunitas tubuh. Bila teraktivasi oleh antigen, Th akan merangsang baik respon imun seluler maupun respon imun humoral, sehingga seluruh sistem imun akan terpengaruh. Namun yang terutama sekali mengalami kerusakan adalah sistem imun seluler. Jadi akibat HIV akan terjadi gangguan jumlah maupun fungsi Th yang menyebabkan hampir keseluruhan respon imunitas tubuh tidak berlangsung normal. ${ }^{7}$

\section{a. Imun Seluler}

Untuk mengatasi organisme intra seluler seperti parasit, jamur dan bakteri intraseluler yang paling diperlukan adalah respon imunitas seluler yang disebut Cell Mediated Immunity (CMI). Fungsi ini dilakukan oleh sel makrofag dan CTLs (cytotoxic T Lymphocyte atau TC), yang teraktivasi oleh sitokin yang dilepaskan oleh limfosit CD4. Demikian juga sel NK (Natural Killer), yang berfungsi membunuh sel yang terinfeksi virus atau sel ganas secara direk non spesifik, disamping secara spesifik membunuh sel yang di bungkus oleh antibody melalui mekanisme antibody dependent cell mediated cytotoxicity (ADCC). Mekanisme ini tidak berjalan seperti biasa akibat HIV. Sel Th : Jumlah dan fungsinya akan menurun. Pada umumnya penyakit indikator AIDS tidak terjadi sebelum jumlah CD4 mencapai 200/uL bahkan sebagian besar setelah CD4 mencapai 100/uL. Makrofag : Fungsi fagositosis dan kemotaksisnya menurun, termasuk juga kemampuannya menghancurkan organisme intra seluler, misalnya kandida albikans dan toksoplasma gondii. Sel Tc : 
Kemampuan sel T sitotoksik untuk menghancurkan sel yang terinfeksi virus menurun, terutama pada infeksi stadium lanjut, sehingga terjadi reaktivasi virus yang tadinya laten, seperti herpes zoster dan retinitis sitomegalo. Demikian juga sering terjadi differensiasi sel ke arah keganasan atau malignansi. Sel NK : Kemampuan sel NK untuk menghancurkan secara langsung antigen asing dan sel yang terinfeksi virus juga menurun. Belum diketahui dengan jelas apa penyebabnya, diperkirakan kemungkinan karena kurangnya IL-2 atau efek langsung HIV. ${ }^{8}$

\section{b. Imunitas Humoral}

Imunitas humoral adalah imunitas dengan pembentukan antibodi oleh sel plasma yang berasal dari limfosit B, sebagai akibat sitokin yang dilepaskan oleh limfosit CD4 yang teraktivasi. Sitokin IL-2, BCGF (B cell growth factors) dan $\mathrm{BCDF}$ ( $B$ cell differentiation factors) akan merangsang limfosit $B$ tumbuh dan berdifferensiasi menjadi sel Plasma. Dengan adanya antibody diharapkan akan meningkatkan daya fagositosis dan daya bunuh sel makrofag dan neutrofil melalui proses opsonisasi. HIV menyebabkan terjadi stimulasi limfosit B secara poliklonal dan non-spesifik, sehingga terjadi hipergammaglobulinaemia terutama IgA dan IgG. Disamping memproduksi lebih banyak immunoglobulin, limfosit B pada odha (orang dengan infeksi HIV/AIDS) tidak memberi respon yang tepat Terjadi perubahan dari pembentukan antibodi IgM ke antibodi IgA dan IgG. Infeksi bakteri dan parasit intrasel menjadi masalah berat karena respons yang tidak tepat, misalnya reaktivasi Toxoplasma gondii atau CMV tidak direspons dengan pembentukan immunoglobulin $\mathrm{M}(\mathrm{IgM}){ }^{9}$

\section{FASE INFEKSI AKUT}

Setelah transmisi HIV melalui mukosa genital yang merupakan transmisi utama, sel dendritic (DC) yang ada di lamina propria mukosa vagina akan menangkap HIV. Sel dendritik bertindak sebagai antigen presenting cell (APC) dan mempresentasikan HIV ke sel limfosit CD4 sehingga dapat merangsang limfosit $\mathrm{T}$. Hal ini terjadi karena sel dendritik mengekpresikan molekul major histocompatibility complex (MHC) klas
I, MHC klas II dan molekul kostimulator lain pada permukaannya. Setelah HIV tertangkap DC akan menuju kelenjar limfoid dan mempresentasikannya kepada sel limfosit $\mathrm{T}$. Disamping mengangkut HIV kekelenjar limfe, sel dendritik juga mengaktivasi sel limfosit CD4, dengan demikian akan meningkatkan infeksi dan replikasi HIV pada sel limfosit Th. Terikatnya HIV ke DC melalui pengikatan protein envelop gp 120 pada sekelompok molekul yang disebut $C$-type lectin receptor. Termasuk dalam $C$-type lectin receptor adalah dendritic cel-specific ICAM -3grabbing non-integrin (DC- SIGN), mannose receptor dan Langerin. Masing-masing molekul ini dapat mengikat gp 120 dan ini lalu dipresentasikan pada sel DC yang berbeda. DC sel mengekspresikan molekul CD4 dan molekul CCR5 tapi tidak mempunyai CXCR4. Mungkin ini berpengaruh dan dapat menjelaskan mengapa hampir $95 \%$ strain HIV yang ditemukan pada infeksi primer adalah strain M- tropik atau R5 HIVstrain. Sama seperti transmisi mukosa, transmisi HIV secara vertikal juga terutama Strain R5. Pada manusia waktu lama dari infeksi mukosa sampai terjadi viremia, berkisar antara 4-11 hari. Hal ini juga tergantung dari apakah ada hal-hal lain yang merusak barier mukosa, seperti misalnya inflamasi dan infeksi (cervisitis, urethritis, ulkus genitalis, dsb). ${ }^{9}$

HIV baik sebagai virus bebas ataupun yang berada dalam sel yang terinfeksi akan menuju kelenjar limfe regional dan merangsang respon imun seluler maupun humoral. Mobilisasi limfosit ke kelenjar ini justru menyebabkan makin banyak sel limfosit yang terinfeksi. Dalam beberapa hari akan terjadi limfopenia dan menurunnya limfosit CD4 dalam sirkulasi. Dalam fase ini didalam darah akan ditemukan HIV bebas titer tinggi dan komponen inti p24, yang menunjukkan tingginya replikasi HIV yang tidak dapat dikontrol oleh sistim imun. Dalam 2-4 minggu akan terjadi peningkatan jumlah sel limfosit total yang disebabkan karena tingginya subset limfosit CD8 sebagai bagian dari respon imunitas seluler terhadap HIV. ${ }^{10}$

Setelah fase akut, akan terjadi penurunan jumlah HIV bebas dalam plasma maupun dalam sel. Masih belum jelas, mengapa bisa demikian, akan tetapi analogi dengan infeksi virus pada umumnya. Sel limfosit T sitotoksik CD8 yang sebagai efektor sel dapat mengontrol infeksi akut oleh virus, karena 
dia bisa mengenal dan menghancurkan sel yang telah terinfeksi (ini kadang- kadang dapat merugikan juga), sehingga dapat mencegah replikasi dan pembantukan virus baru. Pada infeksi HIV sejak awal ditemukan tingginya jumlah sel $\mathrm{T}$ limfosit sitotoksik (TCLs atau Tc). Sel limfosit sitotoksik yang mempunyai petanda CD8, akan teraktivasi oleh HIV dan akan mengeluarkan sejumlah solubel sitokin (termasuk CAF ), yang dapat menghambat replikasi HIV dalam limfosit CD4. Keadaan seperti ini juga terjadi pada infeksi HIV akut, bahkan sebelum serokonversi. Disamping jumlahnya menurun, maka fungsi limfosit CD4 juga terganggu, bahkan pada stadium dimana jumlahnya masih diatas 500/ml. Ternyata kemampuannya untuk proliferasi karena rangsangan berbagai macam antigen dan kemampuannya untuk memproduksi sitokin untuk fungsi helper juga menurun.Terjadi penurunan respon pengenalannya terhadap antigen bakteri, virus atau toksin yang pernah dikenal, lalu hilangnya respon terhadap sel asing (allogeneic response).

\section{FASE KRONIK}

Pada fase transisi ke fase kronik, terjadi switch dari ekspresi sel-secara individual ke bentuk trapping HIV oleh jaringan sel dendritik folikuler didalam germinal senter kelenjar limfe. Bentuk ini mendominasi keberadaan HIV dan pada saat ini terjadi penurunan secara drastis jumlah sel-sel individual yang mengekspresikan HIV. Jadi pada fase akut ini dapat dilihat adanya upaya sel-sel limfosit $\mathrm{T}$ sitotoksik untuk mengurangi jumlah HIV. akan membentuk kompleks dengan imunoglobulin dan komplemen. Kompleks ini akan terikat pada reseptor komplemen pada permukaan sel dendritik. Secara klinik akan terjadi penurunan jumlah RNA HIV dalam plasma dan menghilangnya sindroma infeksi akut. Terjadinya gejala- gejala AIDS umumnya didahului oleh percepatan penurunan jumlah limfosit CD4, sering terjadi pada keadaan dimana sebelumnya jumlah limfosit CD4 diatas 300/uL. Pada umumnya perubahan ini berkorelasi dengan munculnya strain HIV yang lebih virulen, yaitu strain SI (Syncitial Inducing), diikuti oleh gejala klinis menghilangnya gejala limfadenopati generalisata yang merupakan prognosis yang buruk. Hal ini terjadi akibat hilangnya kemampuan respon imun seluler untuk melawan turnoverHIV dalam kelenjar limfe, ditandai oleh meningkatnya HIV kedalam sirkulasi karena rusaknya struktur kelenjar limfe. ${ }^{11}$

Pada infeksi HIV terjadi kehilangan CD4 yang massif, baik oleh akibat virus sendiri maupun aktivasinya pada sistem imun yang dapat menyebabkan apoptosis CD4. Kehilangan CD4 ini dikarenakan produksi pada sumsum tulang yang menurun, peningkatan degradasi pada organ limfoid, dan penggunaannya yang meningkat. Makrofag dan sel dendritik menjadi antigen presenting cell (APC) yang merespon sinyal infeksi. Hal ini berbeda dengan infeksi HIV. Makrofag yang menangkap virus ini menjadi mediator terjadi apoptosis sel dan selain itu perpindahannya ke organ limfoid dapat meningkatkan penyebaran infeksinya. Makrofag yang akan menangkap HIV akan menghasilkan chemo-attractant untuk $T$ cell dan $N K$ cell. kedua sel ini akan menempati reseptor CXCR3 (Chemokine reseptor 3) sehingga Th 1 akan bermigrasi ke kelenjar getah bening dan memberikan respon sebagai Th 1 chemokine. Namun pada pasien yang terinfeksi HIV, CXCR3 ini menetap pada kelenjar getah bening dan dapat memberatkan penyakitnya. Pada awalnya interferon 1 dan IL-12 mendukung diferensiasi Th1 menghasilkan IFN-ã dalam jumlah banyak untuk mengaktifkan makrofag menghasilkan chemokine dan disisi lain produksi IL 4 ditekan. Interaksi Th 1 dengan makrofag akan menghasilkan IFN-ã lebih banyak lagi dan pelepasan CXCL10 (Chemokine Ligand 10). CXCR3 yang berikatan dengan Th 1 dapat menekan produksi Th 2 sehingga keseimbangannya dapat diatur. Ketidakseimbangan chemokine yang dihasilkan mempengaruhi progresivitas infeksi HIV. ${ }^{11}$

\section{IMUNOLOGI HIV PADA KEHAMILAN}

Kehamilan menjadi tantangan besar bagi pengaturan sistem imun. ${ }^{12}$ Fungsi imun ditekan baik pada wanita terinfeksi HIV maupun tidak terinfeksi HIV. Selama kehamilan terjadi penurunan immunoglobulin, penurunan jumlah komplemen, dan penurunan imunitas seluler. ${ }^{12}$ Nomalnya kehamilan akan membuat progresvitas HIV pada kehamilan memburuk. Pada penelitian di Perancis 
mengelompokkan 57 wanita hamil dengan HIV dan 114 wanita hamil tanpa terinfeksi HIV dan dikuti selama 61 bulan ternyata tidak ada perbedaan progresivitas yang bermakna ${ }^{12}$. Penelitian di Switzerland mengelompokkan 32 HIV dalam kehamilan dan 416 HIV tidak hamil yang deperhitungkan usia dan jumlah CD4nya diikuti selama 4,8 tahun untuk hamil dan 3,6 tahun untuk kontrol ${ }^{13}$. Hasilnya menunjukkan tidak ada perbedaan progresivitas penyakit dan rata-rata usia kematiannya, kecuali sudah terdapat infeksi seperti pneumoni bakteri. ${ }^{13}$

Respon imun fetal maternal pada kehamilan dipengaruhi oleh timus sebagai toleransi pusat dan $\mathrm{T}$ reg ( $\mathrm{T}$ regulator) sebagai pengatur toleransi perifer. Ukuran dan strukstur thymus mengecil selama kehamilan, namun ukuran dan fungsinya akan kembali normal setelah post partum. 93,14 Sedikitnya Treg pada kehamilan memicu terjadinya abortus, stillbirth, berat badan lahir rendah, persalinan premature. Keseimbangan Th1 dan Th2 enjadi suatu hal penting untuk dicapai dalam mempertahankan kehamilan. Infeksi HIV menyebabkan penurunan jumlah CD4 dan Th 2, dan penurunan aktivasi imun lain. Pada penelitian yang membandingkan penggunaan HAART meunjukkan perbedaan profil imunologi yang bermakna. ${ }^{15}$ Proses pengaturan imunologi sistemik berubah pada saat kehamilan. Penelitian pada tikus menunjukkan peningkatan T reg sejak awal kehamilan yang dipicu oleh antigen paternal. Kegagalan kehamilan pun dapat terjadi bila tidak adanya $\mathrm{T}$ reg ini. Penelitian pada manusia juga menunjukkan hal yang sama; sedikitnya $\mathrm{T}$ reg pada lapisan desidual dapat menginduksi abortus, preeklampsia, dan infertilitas. ${ }^{16}$ Pada HIV negative $\mathrm{T}$ reg diperluas saat awal kehamilan dan akan menurun lebih rendah lagi setelah post partum. Berbeda dengan infeksi HIV, T reg tidak berubah hingga trimenter kedua. Treg pada infeksi HIV diakumulasikanpada jaringan limfoid dan pada post partum jumlah $\mathrm{T}$ reg lebih tinggi pada pasien infeksi HIV dibandingkan dengan HIV negatif. ${ }^{17,18}$

Sutton, dkk membuktikan dalam penelitiannya bahwa produksi interleukin-2 IL-2 pada wanita tidak hamil HIV negative lebih tinggi dibandingkan dengan positif HIV. Produksi IL 2 padawanita hamil dikatakan menurun pada seluruh trimester kehamilan. Produksi IL 2 pun tidak meningkat dengan pemberiaan antivirus kombinasi. ${ }^{19}$

Human Leucocyte antigen-G (HLA-G) dapat menghambat respon imun cell mediated dan dapat menembus plasenta menyebarkan infeksi HIV-1 sehingga meningkatkan risiko transmisi vertikal. Selain itu Major Histocompatibility Complex (MHC) mengkode HLA-G untuk menghambat natural killer cell (NK cells) sehingga mendukung masuknya virus melewati barrier plasenta pada wanita hamil positive HIV 1. Rendahnya NK cell akan meningkatkan isiko transmisi vertikal. ${ }^{19}$

Aktivasi CD38 dan HLA-DR pada sel Tmenjadi indicator aktivasi sel. Infeksi HIV mengaktivasi CD8 untuk menekspresikan antigen HLA-DR. aktivasi imun CD8 pada kehamilan mempengaruhi progresivitas imun tidak baik. Kehamilan yang mempengaruhi aktivasi imun sel T CD8 berhubungan erat dengan jumlah CD4 sebagai indicator status imunitas. Kehamilan akan menekan ekspresi limfosit CD8 ini, kehamilan tidak mempengaruhi aktivasi CD8, namun aktivasi CD8 akan menurun pada wanita hamil positif HIV. Aktivasi imun kronik CD8 pada HIV menjadi faktor menurunnya jumlah CD4. Ekspresi HLA-DR dan CD38 pada limfosit T CD8 akan mengenali CD4 yang dieliminasi oleh infeksi HIV. Jumlah CD8, CD38, dan HLA-DR yang menurun pada wanita hamil positif HIV dapat menjadi parameter prognostik status imunitasnya. ${ }^{19}$

\section{PENUTUP}

Infeksi HIV akan menurunkan jumlah sel CD4+ yang disebabkan oleh efek sitopatik virus dan kematian sel. Jumlah sel $\mathrm{T}$ yang hilang selama perjalanan dari mulai infeksi hingga tahap lanjut jauh lebih besar dibandingkan jumlah sel yang terinfeksi, hal ini diduga akibat sel $\mathrm{T}$ yang diinfeksi kronik diaktifkan dan rangsang kronik menimbulkan apoptosis. Kehamilan yang mempengaruhi aktivasi imun sel T CD8 berhubungan erat dengan jumlah CD4 sebagai indicator status imunitas. Kehamilan akan menekan ekspresi limfosit CD8 ini, kehamilan tidak mempengaruhi aktivasi CD8, namun aktivasi CD8 akan menurun pada wanita hamil positif HIV. 


\section{DAFTAR PUSTAKA}

1. World Health Organization. Data on the size of the HIV/AIDS epidemic: data by WHO region by WHO region. WHO. 2012. Diunduh pada http://apps.who.int/gho/data/ node.main.619?lang=en tanggal 2 Maret 2012.

2. World Health Organization. Data on the size of the HIV/AIDS epidemic: Number of people (all ages) living with HIV by country. WHO. 2012. Diunduh pada http://apps.who.int/gho/data/ node.main.620?lang=en tanggal 2 Maret 2012.

3. Freed EO, Englund G, Martin MA. Role of the basic domain of human immunodeficiency virus type 1 matrix in macrophage infection. J Virol. 1995;69(6):3949-54.

4. Lackner AA, Veazey RS. Current concepts in AIDS pathogenesis: insights from the IV/ macaque model. Annu Rev Med. 2007;58:46176.

5. Tomaras GD, Yates NL, Liu P, Qin L, Fouda GG, Chavez LL, et al. Initial B-cell responses to transmitted human immunodeficiency virus type 1: virion-binding immunoglobulin $\mathrm{M}(\operatorname{IgM})$ and IgG antibodies followed by plasma anti-gp41 antibodies with ineffective control of initial viremia. J Virol. 2008;82(24):12449-63.

6. Zhang Z, Schuler T, Zupancic M, Wietgrefe S, Staskus KA, Reimann KA, et al. Sexual transmission and propagation of SIV and HIV in resting and activated CD4+ $\mathrm{T}$ cells. Science. 1999;286(5443):1353-7.

7. Palmer S, Wiegand AP, Maldarelli F, Bazmi H, Mican JM, Polis M, et al. New real-time reverse transcriptase-initiated PCR assay with singlecopy sensitivity for human immunodeficiency virus type 1 RNA in plasma. J Clin Microbiol. 2003;41(10):4531-6.

8. Li H, Bar KJ, Wang S, Decker JM, Chen Y, Sun C, et al. High Multiplicity Infection by HIV-1 in Men Who Have Sex with Men. PLoS Pathog. 2010;6(5):e1000890.

9. Alter G, Martin MP, Teigen N, Carr WH, Suscovich TJ, Schneidewind A, et al. Differential natural killer cell-mediated inhibition of HIV-1 replication based on distinct KIR/HLA subtypes. J Exp Med. 2007;204(12):3027-36.

10.Hladik F, Sakchalathorn P, Ballweber L, Lentz G, Fialkow M, Eschenbach D, et al. Initial events in establishing vaginal entry and infection by human immunodeficiency virus type-1. Immunity. 2007;26(2):257-70.

11. Schmitz JE, Kuroda MJ, Santra S, Sasseville VG, Simon MA, Lifton MA, et al. Control of viremia in simian immunodeficiency virus infection by CD8+ lymphocytes. Science. 1999; 283(5403):857-60.

12.Rajeev Mehla PD. Chemokine Deregulation in HIV. Infection: Role of Interferon Gamma Induced Th1-Chemokine Signaling. J Clin Cell Immunology. 2012.

13.Aluvihare VR, Kallikourdis M, Betz AG. Tolerance, suppression and the fetal allograft. J Mol Med (Berl). 2005;83(2):88-96.

14.Aluvihare VR, Kallikourdis M, Betz AG. Regulatory $\mathrm{T}$ cells mediate maternal tolerance to the fetus. Nat Immunol. 2004;5(3):266-71.

15. Zoller AL, Schnell FJ, Kersh GJ. Murine pregnancy leads to reduced proliferation of maternal thymocytes and decreased thymic emigration. Immunology. 2007;121(2):207-15.

16.Ono E, Dos Santos AM, Machado DM, Succi RC, Amed AM, Salomao R, et al. Immunologic features of HIV-1-infected women on HAART at delivery. Cytometry B Clin Cytom. 2008;74(4):236-43.

17.Guerin LR, Prins JR, Robertson SA. Regulatory T-cells and immune tolerance in pregnancy: a new target for infertility treatment? Hum Reprod Update. 2009;15(5):517-35.

18. Nilsson J, Boasso A, Velilla PA, Zhang R, Vaccari M, Franchini G, et al. HIV-1-driven regulatory T-cell accumulation in lymphoid tissues is associated with disease progression in HIV/ AIDS. Blood. 2006;108(12):3808-17.

19. Sutton MY, Holland B, Denny TN, Garcia A, Garcia Z, Stein D, et al. Effect of pregnancy and human immunodeficiency virus infection on intracellular interleukin-2 production patterns. Clin Diagn Lab Immunol. 2004;11(4):780-5. 